\title{
Pengaruh Tanggal Kadaluarsa dan Label Halal pada Kemasan Produk Makanan terhadap Keputusan Pembelian Masyarakat Sungai Terap Muaro Jambi
}

\author{
Ahmad Tarmizi, Ulyah \\ Fakultas Ekonomi dan Bisnis Islam UIN Sulthan Thaha Saifuddin Jambi
}

\begin{abstract}
Abstrak: Tulisan ini mendalami pengaruh tanggal kadaluarsa dan label halal pada kemasan produk makanan terhadap keputusan pembelian masyarakat desa Sungai Terap Kecamatan Kumpeh Ulu Kabupaten Muaro jambi tahun 2018. Metode penelitian adalah kuantitatif dengan pengumpulan data melalui angket dan observasi. Sampel dalam penelitian ini berjumlah 90 orang. Analisis yang digunakan dalam penelitian ini yaitu, uji validitas, uji reabilitas, analisis regresi linear berganda, uji T, uji F, dan analisis koefisien determinasi. Penelitian dilakukan dengan persamaan regresi linear berganda untuk pengaruh tanggal kadaluarsa dan label halal adalah $\mathrm{Y}=0,292(\mathrm{X} 1)+0,436(\mathrm{X} 2)+\mathrm{e}$. pengaruh tanggal kadaluarsa dan label halal bersama - sama berpengaruh signifikan terhadap keputusan pembelian dikarenakan hasil uji $\mathrm{F}$ yang dilakukan menghasilkan nilai $\mathrm{F}$ hitung $>\mathrm{F}$ tabel atau 14,551 > 2,71 dengan nilai signifikan (sig) sebesar 0,000> level of signifikan0,05. Nilai koefisien determinasinya adalah 0,578 berarti besarnya pengaruh tanggal kadaluarsa dan label halal bersama-sama berpengaruh terhadap keputusan pembelian dilihat dari $\mathrm{R}^{2}$ yaitu 57,8\% sedangkan sisanya 42,2\% dipengaruhi faktor lain.

Kata- kata kunci: tanggal kadaluarsa, label halal, keputusan membeli, Sungai Terap.
\end{abstract}

\section{Pendahuluan}

Seiring dengan pesatnya perkembangan media saat ini, arus informasi yang diperoleh konsumen akan semakin banyak dan dapat pula mempengaruhi pola konsumsi konsumen. ${ }^{1}$ Dalam melakukan pembelian, konsumen akan dihadapkan oleh beberapa tahapan dalam pengambilan keputusan pembelian baik itu sebelum maupun setelah melakukan pembelian. Keputusan pembelian, yaitu konsumen akan membentuk pertimbangan atas merek-merek pilihan yang akan dibeli, di mana konsumen juga mungkin membentuk niat untuk membeli produk yang paling disukai nya. Sedangkan Keputusan pasca-pembelian, yaitu setelah membeli suatu produk, konsumen akan mengalami tingkat kepuasan atau ketidak puasan tertentu yang akan memengaruhi perilaku pembelian berikutnya. Konsumen yang puas cenderung akan menjadi sarana yang baik dalam mempromosikan produk tersebut kepada orang lain. ${ }^{2}$

Dalam membeli makanan terutama makanan dalam kemasan, seharusnya sebelum membeli produk tersebut pembeli melihat tanggal yang diberi untuk membatasi tingkat keamanan produk (tanggal kadaluarsa) Sayangnya, tak semua orang memahami atau jeli membaca tanggal dan makanan kadaluarsa berikut

1 Tengku Putri Lindung Bulan, "Pengaruh Labelisasi Halal terhadap Keputusan Pembelian Sosis .di Kuala Simpang Kabupaten Aceh Tamiang." hlm. 43.

2 Davin Joshua \& Metta Padmalia, Pengaruh Kualitas Produk dan Harga Terhadap Keputusan Pembelian Konsumen". HIm. 28. 
maksud dibalik keterangan di label kemasan tersebut. Pakar diet dan ahli fisiologi, dr. Graca Judio-Hahl, MSc,HM.CHt, dari klinik lighthouse Indonesia menjelaskan yang dimaksud dengan tanggal kadaluarsa biasanya tanggal ini berdasarkan jangka waktu yang di tetapkan produsen sebagai antisipasi penurunan kualitas makanan atau minuman yang diproduksinya. Dalam menetapkan Expired Date (ED), produsen biasanya sudah melakukan serangkaian tes, melihat dari perubahan fisik, bau, dan dari jumlah bakteri yang tumbuh. " Produsen akan mengambil tanggal atau menetapkan jangka waktu sebelum batas maksimal. Misalnya," jelas dari dr.Grace.

Bila kualitas makanan atau minuman sudah jelek, efeknya akan terjadi saat itu juga. Hal yang paling dihawatirkan dari makanan kedaluarsa adalah pertumbuhan bakteri. "bakteri dalam makanan kedaluwarsa bisa menimbulkan efek seperti keracunan makanan, yaitu diare, demam, kejang, muntah.” Efeknya tergantung dari bakteri yang tumbuh dan terjadi di hari yang sama atau di esok harinya jika konsumsi makanan atau minuman kedaluarsa itu dilakukan pada malam hari. " tetapi biasanya kalau dari bentuk fisik makanan masih baik, tidak ada bau, biasanya kualitasnya masih baik." Hal ini mengingat sudah ada antipasi produsen dengan mengambil jeda waktu yang lebih singkat dari durasi pertumbuhan bakteri pada makanan." Pada hari ED biasnya kualitas belum memburuk. Setelah ED kualitas memang sudah tidak dijamin oleh produsen, tapi belum tentu beracun." Pada tanggal kedaluarsa sebenarnya kualitas masih di jamin produsen. " Tapi, diluar tanggal itu kualitas sudah memburuk atau tidak dijamin lagi. Buruk dalam arti ada perubahan warna, kerenyahan berkurang, atau makanan makin kering." Perhatikan perubahan - perubahan tersebut jika ingin mengecek makanan atau minuman yang akan dikonsumsi. " yang harus dicatat adalah, kalau sudah ada perubahan bakteri. Ini yang akan berefek pada kesehatan tubuh."3Selain melihat kehigienisan dan expired date pada makanan kemasan, umat Islam juga wajib melihat label halal pada produk makanan kemasan tersebut. Karena Setiap muslim diwajibkan untuk mengonsumsi makanan halal.

Mengonsumsi produk-produk haram, baik berupa pangan. (makanan dan minuman), obat, dan kosmetik, adalah sesuatu yang harus dihindari oleh setiap muslim. Hal itu karena mengkonsumsi produk - produk haram tidak hanya akan membahayakan secara fisik bagi yang bersangkutan, tetapi juga membawa konsekuensi ukhrawi. ${ }^{4}$ Dalam Islam umat muslim diwajibkan mengkonsumsi makanan yang halal, karena setiap makanan yang umat Islam konsumsi akan mendarah daging dalam tubuh dan menjadi sumber energi yang penting untuk kehidupan. Rasulullah s.a.w bersabda: "Tidaklah tumbuh daging dari makanan haram, kecuali neraka lebih utama untuknya." (HR At-Tirmidzi). Ketidak inginan masyarakat Muslim untuk mengkonsumsi produk-produk haram akan meningkatkan kejelian dalam proses pemilihan produk (high involvement).

3 Noverita. Membedakan Istilah 'Expired Date' dan 'Best Before' pada Kemasan Makanan: Tribun Kesehatan 2017.

${ }^{4}$ HIMPUNAN FATWA MUI Sejak 1975,: 2011, Penerbit Erlangga, hlm. 916 
Sehingga akan ada produk yang dipilih untuk dikonsumsi dan produk yang tersisih. ${ }^{5}$

Setiap konsumen punya hak untuk memperoleh jaminan bahwa produk produk yang di konsumsinya adalah halal. Sementara tidak semua konsumen, seiring dengan rumitnya masalah teknologi pangan yang terus berkembang, dapat mengetahui kehalalan produk makanan. ${ }^{6}$ Undang-Undang Dasar Negara Republik Indonesia Tahun 1945 Pasal 29 ayat (2) mengamanatkan Negara menjamin kemerdekaan tiap-tiap penduduk untuk memeluk agamanya masing-masing dan untuk beribadah menurut agamanya dan kepercayaannya itu. ${ }^{7}$ Untuk menjamin setiap pemeluk agama beribadah dan menjalankan ajaran agamanya, Negara berkewajiban memberikan perlindungan dan jaminan tentang kehalalan produk yang dikonsumsi dan digunakan konsumen muslim. ${ }^{8}$

Saat ini kurang memperhatikan kehalalan suatu produk. Padahal untuk memproduksi suatu produk tidak hanya memperhatikan bahan bakunya saja. Kehalalan suatu produk perlu dipertimbangkan. Karena dengan menjalani ajaran agama, menghendaki agar produk-produk yang dikonsumsi terjamin kehalalannya dan kesucianya secara hukum. ${ }^{9}$ Kehalalan sebagai parameter utama dalam proses pemilihan produk. Ketentuan ini membuat keterbatasan pada produk-produk makanan untuk memasuki pasar umat Muslim. Memastikan makanan yang di konsumsi halal menjadi tanggung jawab bagi setiap muslim. Untuk mempermudah mengetahui makanan yang di konsumsi halal khususnya makanan dalam kemasan maka dapat dilihat dari label halal yang tercantum pada kemasan makanan tersebut. Label pada produk pangan hal yang sangat penting untuk diperhatikan. ${ }^{10}$

Dari latar belakang diatas dapat diketahui bahwa tanggal kadaluarsa menjelaskan tentang sejauh mana makananan kemasan tersebut layak dikonsumsi manusia dan apabila melewati tanggal kadaluarsa apa saja yang akan terjadi pada tubuh manusia tersebut. Sedangkan label halal menunjukkan bahwa produk tersebut tidak bercampur dengan bahan haram dan lain seterusnya. Umat islam wajib memakan makanan yang halal, sebaliknya masyarakat harus memakan makanan yang halal. Hal ini telah diperintahkan oleh Allah Swt pada QS.Surah Al Baqarah ayat 168.

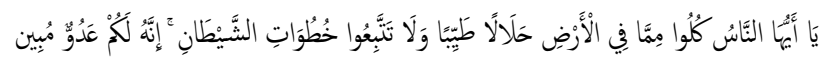

"Hai manusia, makanlah yang halal lagi baik dari apa yang terdapat di bumi dan janganlah kamu mengikuti langkah-langkah syaithan; karena

5 Yuli Mutiah Rambe dan Syaad Afifuddin, Pengaruh Pencantuman Label Halal Pada Kemasan Mie Instan Terhadap Minat Pembelian Masyarakat Muslim (Studi Kasus Pada Mahasiswa Universitas Al-Washliyah, Medan) Vol .1 No. 1 Desember 2012

${ }^{6}$ Ibid.

7 UUD 1945 dan AMANDEMEN Indonesia Bersama II 2009 -2014 ( Eidisi Reshuffle ) AGAMA, pasal 29. hlm. 48

8 Ibid. hlm. 160

${ }^{9}$ Erna Restu Hidayah, Pengaruh Labelisasi Halal Terhdap Keputusan Pembelian (Studi Pada Depot Air Mineral Shofiro Bantarsoka, Purwokerto, Banyumas).

10 Ibid. hal 36 
sesungguhnya syaitan adalah musuh yang nyata bagimu." (QS. Al-Baqarah: 168) ${ }^{11 .}$

Melalui ayat tersebut Allah Swt memerintahkan memamakan makanan yang halal dan tayyib. Pada era global makanan layak dikonsumsi sebelum masa mengonsumsinya habis (tanggal kadaluarsa) dan label halal telah dicantumkan sebagian didalam makanan kemasan yang telah melewati pengujian sebelum diberikan pencatuman tanggal kadaluarsa dan label halal yang layak dikonsumsi oleh manusia. Persoalan yang dapat didalami apakah dengan tercantumnya tanggal kadaluarsa dan label halal apakah masyarakat terutama ibu rumah tangga yang sering berbelanja kebutuhan sehari-hari pengaruh atau tidakah dalam keputusan pembelian suatu produk makanan kemasan tersebut dengan tercantumnya tanggal kadaluarsa dan label halal tersebut.

Berdasarkan dengan latar belakang diatas, maka permasalahan utama yang akan dibahas dalam tulisan ini adalah apakah tanggal kadaluarsa dan label halal pada kemasan produk makanan berpengaruh terhadap keputusan pembelian masyarakat desa Sungai Terap secara persial dan simultan.

\section{Tanggal Kadaluarsa dan Label Halal}

Pengertian kadaluarsa dalam Peraturan Menteri Kesehatan RI telah mengalami perubahan, karena berdasarkan Peraturan Menteri Kesehatan nomor 346/men. Kes/per/IX/1983, Pengertian tanggal kadaluarsa adalah batas waktu akhir suatu makanan dapat di gunakan sebagai makanan manusia. ${ }^{12}$ Tanggal kadaluarsa merupakan informasi dari produsen kepada konsumen, yang menyatakan batas/tenggang waktu penggunaan/pemanfaatan yang paling baik dan paling aman dari produk makanan atau minuman kemasan. Artinya produk tersebut memiliki "mutu yang paling prima" hanya sampai batas waktu tersebut. Dan produsenlah yang menentukan masa tenggang kadaluwarsanya dikarenakan pihak produsenlah yang mengetahui lebih lanjut mengenai produk yang diproduksi.

Di Indonesia, pengaturan mengenai tanggal kadalauarsa pada makanan kemasan cukup banyak ditemukan, diantaranya pada Undang-Undang Dasar Negara Republik Indonesia Tahun 1945 secara eksplisit pada pasal 28D dinyatakan bahwa setiap orang berhak atas jaminan, perlindungan, serta kepastian hukum. Dalam kaitannya dengan perlindungan konsumen terlihat jelas bahwa konsumen memiliki hak atas terjaminnya barang atau jasa yang akan dipakainya, perlindungan terhadap dirinya dari barang atau jasa tersebut, serta kepastian hukum dalam upaya yang ditempuh apabila terjadi kerugian akibat barang atau jasa tersebut di kemudian hari.

Selanjutnya, dalam Pasal 8 ayat (1) huruf g Undang-Undang Nomor 8 Tahun 1999 tentang Perlindungan Konsumen, pada bagian perbuatan yang dilarang bagi pelaku usaha dinyatakan jelas bahwa pelaku usaha dilarang untuk tidak

11 QS. Al-Baqarah: 168

12 Lilik Sri Munah," Memperjualbelikan Makanan dan Minuman Kedakuwarsa Menurut Fiqih Muamalah (Studi Kasus di Desa Kumbara Utama Kecamatan Kerinci Kanan Kabupaten Siak)". HIm.2 
mencantumkan tanggal kadaluarsa atau jangka waktu penggunaan/ pemanfaatan yang paling baik atas barang tertentu. Dari segi konsumen, dalam Pasal 4 huruf a secara eksplisit disebutkan bahwa konsumen berhak atas kenyamanan, keamanan, dan keselamatan dalam mengkonsumsi suatu barang yang dikaitkan apabila suatu makanan kemasan tanpa tanggal kadaluarsa dapat membahayakan kesehatan konsumen dan pada Pasal 4 huruf c secara eksplisit juga disebutkan bahwa konsumen berhak atas informasi yang benar, jelas dan jujur mengenai kondisi dan jaminan barang yang dikaitkan dengan pencantuman tanggal kadaluarsa sebagai informasi dari kondisi terbaik suatu makanan kemasan. ${ }^{13}$

Jadi, untuk konsumen cermati kembali kode - kode tersebut pada produk yang ingin anda beli. Sementara untuk produsen sertakan label yang lengkap pada produk milik anda. Hal ini adalah kewajiban bagi setiap produsen. Seperti yang telag diatur dalam peraturan pemerintah nomor 69 tahun 1999 tentang label iklan pangan. Didalamnya tertulis setiap orang yang memproduksi atau menghasilkan pangan yang dikemas di Indonesia untuk diperperdagangkan wajib mencantumkan label pada kemasan produknya. Label - label tersebut tidak hanya tanggal kadaluarsa saja, namun juga memuat nama produk, daftar komposisi, berat bersih, identitas produsen, legalitas, tanggal produksi, tanggal bulan tahun kadaluarsa atau layak dikonsumsi, nomor izin edar pangan, dan ketentuan lainnya. ${ }^{14}$

Perlindungan konsumen terhadap produk cacat merupakan hal yang sangat penting, hal ini diimplementasikan dalam Undang-Undang Perlindungan Konsumen Nomor 8 Tahun 1999 karena kerugian yang diderita oleh seorang pemakai produk yang cacat atau membahayakan, bahkan juga pemakai yang turut menjadi korban, merupakan tanggung jawab mutlak pelaku usaha pembuat produk itu sebagaimana diatur dalam Pasal 19 Undang-Undang Perlindungan Konsumen sehingga pelaku usaha tidak dapat mengelak dari tanggung jawabnya.

Banyak pelaku usaha menolak untuk bertanggung jawab atas kerugian yang timbul akibat ulah pelaku usaha itu sendiri dengan tetap menjual produk yang telah diketahuinya mengandung cacat atau tidak sesuai standar mutu yang ditetapkan, pada roti misalnya roti yang bungkusnya telah rusak tetap di perdagangkan, padahal tentu hal itu akan mengurangi rasa maupun akan menimbulkan berbagai efek yang dapat merugikan konsumen. Dengan dituangkannya tanggung jawab pelaku usaha dalam UUPK memberikan rasa aman kepada konsumen yang apabila terjadi hal sedemikian, konsumen dapat menuntut kepada pelaku usaha, dan pelaku usaha senantiasa berhati-hati dalam memperdagangkan produknya, sehingga terjalin kerjasama yang baik antara pelaku usaha dan konsumen. ${ }^{15}$

13 I Gede Eggy Bintang Pratama, I Ketut Sudjana. Perlindungan Konsumen Terhadap Makanan Kemasan Tanpa Tanggal Kadaluarsa. : Denpasar. Hlm 3-4.

14 Suci Ramadani, Kode Keterangan Produksi \& Kadaluarsa Kemasan Makanan yang Harus Diketahui: 2017.

15 http://www.landasanteori.com/2015/09/pengertian-makanan-kadaluwarsadefinisi.html. 
Label halal berupa tulisan, gambar, atau kombinasi keduanya yang disertakan pada wadah atau kemasan suatu produk dengan cara dimasukkan kedalam, di tempelkan atau dicetak dan merupakan bagian dari kemasan tersebut. Tujuannya untuk memberikan informasi menyeluruh dan secara utuh dari isi wadah atau kemasan prosuk tersebut. Pelabelan pada kemasan produk harus dipersyaratkan sedemikian rupa, sehingga tidak mudah lepas dari kemasan yang mudah untuk dilihat dan dibaca dengan jelas.

Keberadaan label pada suatu produk sangatlah penting. Hal ini dikarenakan label merupakan identitas dari sebuah produk. Dengan adanya label, konsumen bisa membedakan antara produk satu dengan yang lainnya. Selain itu konsumen juga dapat memperoleh produk yang sesuai dengan yang diinginkannya. Adanaya label juga dapat menghilangkan keraguan konsumen dalam membeli suatu produk

Kata halal (ha lal, halaal ) adalah istilah bahasa arab dalam agama islam yang berarti "diizinkan" atau " boleh". Secara etimologi, halal berarti hal-hal yang berarti dan dapat dilakukan karena bebas atau tidak terikat dengan ketentuan ketentuan yang melarangnya. ${ }^{16}$ Istilah halal dalam kehidupan sehari - hari sering digunakan untuk makanan atatupun minuman yang diperoleh untuk konsumsi menurut syariat islam. Sedangkan dalam konteks luas istilah halal merujuk kepda segala sesuatu baik itu tingkah laku, aktivitas, maupun cara berpakain lain dan sebagainya yang diperoleh atau diizinkan oleh hukum Islam.

Allah Swt. Berfirman:

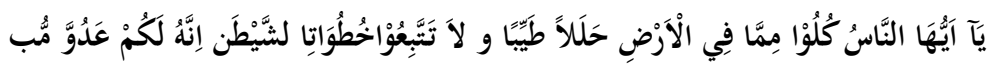

Yang artinya: "Hai sekalian manusia, makanlah yang halal lagi baik dari apa yang terdapat di bumi, dan janganlah kamu mengikuti langkah-langkah syaitan, karena sesungguhnya syaitan itu adalah musuh yang nyata bagimu." (Q.S. al-Baqarah: 168). ${ }^{17}$

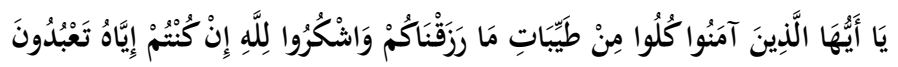

Yang artinya: "Hai orang-orang yang beriman, makanlah di antara rezeki yang baikbaik yang Kami berikan kepadamu dan bersyukurlah kepada Allah, jika benar-benar kepada-Nya kamu menyembah." (Q.S. al-Baqarah: 172). ${ }^{18}$

Berdasarkan surat Al Baqarah tersebut di atas, Allah memerintahkan kepada orang yang beriman untuk memakan makan yang halal dan mengharamkan bangkai, darah, daging babi, daging hewan yang disembelih tidak menyebut nama Allah, kecuali jika terpaksa dan tidak melampaui batas. Untuk menentukan produk makanan dan minuman yang beredar dimasyarakat itu halal harus ada logo sertifikat halal yang dikeluarkan oleh LPPOM MUI pada kemasannya. ${ }^{19}$

\footnotetext{
16 dalam Yusuf Qardhawi, Halal dan Haram Islam,Era Intermedia, Surakarta, 2007, 5.

17 Q.S. al-Baqarah:ayat 168.

18 Q.S. al-Baqarah: ayat 172

${ }^{19}$ Syafrida, Sertifikat Halal Pada Produk Makanan Dan Minuman Memberi Perlindungan Dan Kepastian Hukum Hak - Hak Konsumen Muslim,. HIm163
} 
Ibnu Mas'ud r.a meriwayatkan bahwa Nabi Saw. Bersabda, "Karena beliau bersabda " Mencari sesuatu yang halal adalah kewajiban bagi setiap Muslim". Kerena beliau bersabda bahwa menuntut ilmu adalah kewajiban bagi setiap Muslim, sebagian ulama menfasirkan bhwa maksud " menuntut ilmu " adalah mencari pengetahuan tentang halal dan haram. Jadi, dua hadis itu memiliki maksud yang sama. Nabi Saw bersabda, " barang siapa mencari rezeki halal untuk menfakahi keluarganya, ia laksana mujabid di jalan allah. Barang siapa mencari harta halal untuk menjaga dari keharaman, ia berada pada derajat syuhada (orang - orang yang mati syahid)" (HR Al- Thabarani).

Nabi Saw. Bersabda, "Barang siapa memakan makanan yang halal selama empat puluh hari, niscaya Allah akan menyinari batinnya dan mengalirkan sumber sumber kebijaksanaan dari batinnya ke lidahnya" (HR Abu Nu'aim). Dalam riwayat lain, "...,niscaya Allah menzuhudkan dirinya dalam dunia." ( Zuhud ialah lebih mengutamakan akhirat dari pada dunia-penya. ${ }^{20} \mathrm{Di}$ dalam tuntutan syariat islam, umat Islam dituntut untuk makan dan minum yang halal dan thayib (baik).

Label halal merupakan pencantuman tulisan atau pernyataan halal pada kemasan produk untuk menunjukkan bahwa produk yang dimaksud berstatus sebagai produk halal. ${ }^{21}$ Label halal diperoleh setelah mendapatkan sertifikat halal. Sertifikat halal adalah suatu fatwa tertulis dari Majelis Ulama Indonesia (MUI) yang menyatakan kehalalan suatu produk sesuai dengan syariat Islam. Sertifikat halal ini merupakan syarat untuk mendapatkan ijin pencantuman label halal pada kemasan produk dari instansi pemerintah yang berwenang. Adapun yang dimaksud dengan produk halal adalah produk yang memenuhi syarat kehalalan sesuai dengan syariat Islam. ${ }^{22}$

\section{Pengemasan Produk dan Pembelian Produk}

Para ahli (Philip Khotler\& Kevin Lane Keller) mendefinisikan pengemasan (packaging) sebagai semua kegiatan merancang dan memproduksi wadah umtuk produk. Kemasan (package) bisa mencakup tiga tingkatan bahan. Paco rabance cologne muncul dalam botol (kemasan primer) yang dimasukkan kedalam kotak karton (kemasan sekunder) yang terdapat dalam kotak bergelombang (kemasan pengiriman) yang berisi enam lusin kotak Paco Rabanne. Kemasan yang dirancang dengan baik dapat menciptakan kenyamanan dan nilai promosi. Sebagaimana harus memasukkan pengemasan sebagai senjata pemberian gaya, khususnya dalam produk makanan, kosmetik, perlengkapan mandi, dan peralatan kecil konsumen. Kemasan merupakan hal pertama yang dihadapi pembeli penyangkut produk dan mampu mengubah pembeli. Bagi Arizona tea, kemasan menjadi titik pembuka.

${ }^{20}$ Yusuf Qardhawi, Halal dan Haram , penerbit Jabal, 2007. HIm. 11-13

21 Bagian Proyek Sarana dan Prasarana Produk Halal Direktorat Jenderal Bimbingan Masyarakat Islam dan Penyelenggaraan Haji, Petunjuk Teknis Pedoman System ProduksiHalal, Departemen Agama, Jakarta, 2003,2.

22 Burhanuddin, Pemikiran Hukum Perlindungan Konsumen dan Sertifikat Halal, Malang,UIN Maliki Press, 2011, hlm.140. 
Para pemasaran harus memahami berbagai pengaruh terhadap membeli dan mengembangkan pemahaman mengenai bagaimana sebenarnya para konsumen membuat keputusan pembelian mereka. Para pemasar harus mengidentifikasi siapa yang membuat keputusan pembelian, jenis keputusan pembelian, dan langkah - langkah dalam proses pembelian. ${ }^{23}$ Proses psikologis Dasar ini memainkan peran penting dalam memahami bagaimana konsumen secara aktual mengambil keputusan pembelian. Para pemasar harus memahami setiap sisi perilaku konsumen. ${ }^{24}$

Dalam tahap evaluasi, konsumen membentuk preferensi antarmerek dalam kumpulan pilihan. Konsumen mungkin juga membentuk maksud untuk membeli merek yang paling disukai. Dalam melaksankan maksud pembelian, konsumen dapat membentuk lima sudkeputusan: merek (merek A), penyalur (penyalur 2); kuantitas (satu computer), waktu (akhir minggu), dan metode pembayaran (kartu kredit). ${ }^{25}$

Jumlah dan kompleksitas kegiatan konsumen dalam pembeliannya dapat berbedabeda. Menurut Howard, pembelian konsumen dapat ditinjau sebagai kegiatan penyelesaian suatu masalah, dan terdapat tiga macam situasi.Jenis situasi tersebut adalah : Perilaku responsi rutin, Penyelesaian masalah terbatas dan Penyelesaian masalah ekstensif

Proses konsumen untuk mengambil keputusan pembelian harus dipahami oleh pemasar perusahan dengan tujuan untuk membuat strategi yang tepat. Proses pembuatan keputusan konsumen dalam membeli produk-produk tidak dapat dianggap sama. Pembelian pasta gigi mempunyai proses yang berbeda dengan pembelian sabun mandi atau shampoo. Assael (2010: 67) mengembangkan tipologi dari proses pengambilan keputusan konsumen yaitu : Tingkat pengambilan keputusan dan Tingkat keterlibatan dalam pembelian

Terdapat empat jenis proses pembelian konsumen, yaitu : pengambilan keputusan yang kompleks, pengambilan keputusan yang terbatas, kesetian pada merek, dan inertia. Pembelian yang memiliki keterlibatan rendah, menghasilkan perilaku pengambilan keputusan yang terbatas. Konsumen kadang-kadang melakukan pengambilan keputusan, walaupun memiliki keterlibatan yang srendah terhadap produk. Konsumen kurang memahami kategori produk, pencarian informasi, dan evaluasinya lebih terbatas dibandingkan dengan proses yang kompleks. Contoh produknya adalah macam-macam makanan ringan dan sereal. ${ }^{26}$

23 Abdullah,Tamrin \& Francis Tantri “ Manajemen Pemasaran “ . Jakarta ,2012, Raja Grafinda Persada. Hlm 123.

${ }^{24}$ Khotler, Philip \& Kevin Lane Keller “ Manajemen Pemasaran” edisi kedua belas jilid 1, 2007, Indeks. hlm.234

25 Khotler, Philip \& Kevin Lane Keller “ Manajemen Pemasaran” edisi ketigabelas jilid 1, 2008, Erlangga. HIm. 188

${ }^{26}$ Budhi Satrio, Pengaruh Harga dan Kualitas Produk Tterhadap Keputusan Pembelian, HIm. 4-5 


\section{Penutup}

Berdasarkan hasil analisis data dan pembahasan, maka dapat diambil kesimpulan sebagai berikut: pertama, Variable tanggal kadaluarsa (X1), dengan tingkat signifikansi sebesar 0,002 > 0,05, variable label halal (X2), sebesar 0,000 > 0,05, maka telah memenuhi syarat untuk menjadi variable pendukung dari keputusan pembelian. Variable yang memiliki pengaruh paling besar adalah variable tanggal kadaluarsa dengan tingkat koefisisen sebesar 0,292 kemudian diikuti oleh label halal dengan tingkat koefisien 0,436.

Kedua Dengan menggunakan uji F didapatkan hasil bahwa semua variable independen memiliki pengaruh yang signifikan terhadap variable dependen yaitu keputusan pembelian dengan tingkat signifikasi 0,000 $>0,05$. Hasil perhitungan koefisien determinasi menunjukan bahwa keseluruhan variable dependen yaitu tanggal kadaluarsa (X1), dan label halal (X2) dapat menjelaskan variable keputusan pembelian Y sebesar 57,8\% sisanya 42,2\% di pengaruhi oleh variable lain yang tidak diteliti dalam penenlitian ini. 


\section{BIBLIOGRAFI}

Abdullah, Tamrin \& Francis Tantri, Manajemen Pemasaran, Jakarta: Rajagrafindo Persada, 2012.

Bagian Proyek Sarana dan Prasarana Produk Halal Direktorat Jenderal Bimbingan Masyarakat Islam dan Penyelenggaraan Haji, Petunjuk Teknis Pedoman System ProduksiHalal, Departemen Agama, Jakarta, 2003.

Burhanuddin, Pemikiran Hukum Perlindungan Konsumen dan Sertifikat Halal, Malang, UIN Maliki Press, 2011.

Davin Joshua \& Metta Padmalia, "Pengaruh Kualitas Produk dan Harga Terhadap Keputusan Pembelian Konsumen".

Erna Restu Hidayah, Pengaruh Labelisasi Halal Terhdap Keputusan Pembelian (Studi Pada Depot Air Mineral Shofiro Bantarsoka, Purwokerto, Banyumas).

HIMPUNAN FATWA MUI Sejak 1975, Jakarta Penerbit Erlangga, 2011.

I Gede Eggy Bintang Pratama , I Ketut Sudjana. Perlindungan Konsumen Terhadap Makanan Kemasan Tanpa Tanggal Kadaluarsa. : Denpasar.

Tengku Putri Lindung Bulan, "Pengaruh Labelisasi Halal terhadap Keputusan Pembelian Sosis .di Kuala Simpang Kabupaten Aceh Tamiang."

Noverita, Membedakan Istilah 'Expired Date' dan 'Best Before' pada K emasan Makanan: Tribun Kesehatan 2017.

UUD 1945 dan AMANDEMEN Indonesia Bersama II 2009 -2014 ( Eidisi Reshuffle ) AGAMA, pasal 29.

Syafrida, Sertifikat Halal Pada Produk Makanan Dan Minuman Memberi Perlindungan Dan Kepastian Hukum Hak - Hak Konsumen Muslim,.

Suci Ramadani, Kode Keterangan Produksi \& Kadaluarsa Kemasan Makanan yang Harus Diketahui: 2017.

Yusuf Qardhawi, Halal dan Haram Islam, Era Intermedia, Surakarta, 2007.

Yuli Mutiah Rambe dan Syaad Afifuddin, Pengaruh Pencantuman Label Halal Pada Kemasan Mie Instan Terhadap Minat Pembelian Masyarakat Muslim (Studi Kasus Pada Mahasiswa Universitas Al-Washliyah, Medan) Vol. 1 No. 1 Desember, 2012. 